\title{
Innovative Development of the RF Economic Entities: Structural Aspect
}

Margarita I. Berkovich

\author{
Doctor of Economics, Professor, Kostroma State Technological University, Kostroma, Russia
}

Email: ecdepart@kstu.edu.ru

Nadezhda I. Antipina

Candidate of Economics, Kostroma Region Agency of Investments and Project Support, Kostroma, Russia

Email: ni_antipina@mail.ru

\section{Doi:10.5901/mjss.2016.v7n2p80}

\section{Abstract}

The article defines peculiar features of the RF economic entities innovative development on meso- and microeconomic levels structured according to their size, industrial identity, source of development, pattern of property and development factors and resources. To achieve the goal of research a systematic approach along with some applied methods - comparative and component analysis, benchmarking, which allow to identify and determine peculiarities of innovative activity of different economic agents in the entire economic sphere have been used. Their application is based on the representative published information, presented online which has provided true results and argumentative evaluations. The approach used in the article is aimed at establishing specific functions of different economic operators who failed to attract the researchers' attention. The article speaks about some peculiarities of innovative development of large corporations which being typical operators of mesoeconomic level. In that context the structured aspect is implemented in research of forms of ownership of big corporations particularly by determining the role of the state as the most important business operator and the stockholder. The state can attract financial resources of Federal Research Institutes and leading banks. The complexity of economic relations in the sphere of innovative development is revealed in research of the sector profile of middle and small businesses represented in Russia by a special sector of business - fast-growing medium-sized enterprises as well as "new businesses". The forms of innovative development of these sectors have been identified in connection with the peculiarities of their activity and specific competence.

Keywords: Innovative development, industrial corporations, middle-size fast-growing businesses, "new business", industrial sector

\section{Introduction}

Under present-day conditions of the open economy, increase in global competition and scarcity of development resources, acceleration of innovative development of economic entities on all levels of economic system takes on special significance.

Problems of innovative development of businesses are presented in works by such foreign economists as J.A. Allen, P. Drucker, M. Fischer, C. Freeman, R.R. Nelson, J.A. Schumpeter, along with the Russian ones such as Glazyev S.U., Greenberg R.S., Evseychev A.I., Sorokin D.E. Economists Acerman E.N., Baldin K.V., Berkovich M.I., Goncharenko L.P., Ershova I.V., Kozlovskaya O.V. pay a lot of attention to the problem of institutional provision of innovative business development on macro-, meso-, and micro levels. Research of innovative development on meso level was done by S. Blank, R.G. Cooper, J. Furman, H. Hollanders, I. Nonaka, D.C. North, H. Takeuchi, Kleiner G.B., Babaev B.D., I. M. Bortnik, Dmitriev Y.A., Kistanov V.V., Kopylov N.V., Malin A.S., Popov R.A., Chistobaev A.I. Problems of innovative development of fast-growing medium-sized businesses as well as innovative small businesses are discussed by Z.J. Acs, D. L. Birch, C. Brown, A. Coad, P. Davidsson, S.-O. Daunfeldt, J. Hamilton, D. Johansson, W. Chan Kim, J. Medoff, R. Mauborgne, D.J. Storey and Russian economists T.I. Gurova, U.A. Polunin, M. Totina, A.U. Udanov.

Though the problem of peculiarities of innovative development is highly discussed its structural aspect among various businesses is to be studied. The stated approach was realized by means of identification of innovative development peculiarities of different enterprises classified by D. Birch (Birch, 1994): big, middle-size fast-growing and small. The objects of analysis were three types of enterprises: first-rate Russian industrial corporations (Expert 400, 2014), middle-size fast-growing businesses and a group of small innovative enterprises (the so-called "new business").

By reaching the goal of the research the following tasks can be completed: 
- the problem can be actualized and special features of innovative development of economic sectors of different levels both large innovative corporations and medium-sized and small businesses can be determined;

- to determine peculiarities of innovative development of some big corporations taking into account their sphere of development, pattern of ownership, institutional features including the role of the state and opportunity to attract different resources both material and non-material;

- to determine specific features connected with peculiarities of industrial and innovative infrastructure of successful fast-growing medium-sized businesses;

- to set off small innovative "new" business as a special object for research which is focused on mainly innovative organizational and economic decisions;

- to determine specific activity of less studied businesses (creators of "blue oceans") which is as a rule connected not with the material production but with service and marketing.

Solution of the mentioned above tasks shows how important the research is from the point of view of creating favorable conditions of innovative business sectors by the federal and local authorities.

\section{Research Methods}

The authors' approach deals with the systematic research of the problem of peculiarities of innovative development of Russian businesses of a different size and sector profile. The focus is made on research of innovative leaders and businesses but not all businesses possible which allows to concentrate on less studied phenomena.

Uniqueness of the approach consists in the structured research of the RF economic entities in connection with the issue of their innovative development and defining their peculiarities structured according to their size, pattern of property, industrial identity and innovative forms. Logical order of research is represented in Fig.1.

The choice of this approach is defined by multidimensional character of the research objectives. The chosen methods are most appropriate for carrying out this research and reaching its objectives and the final conclusion is based on the chosen methods.

Representativeness of the data is ensured by both scientific and factual information, including the use of acknowledged ratings of the leading RF rating agencies (e.g. Expert-RA),presented in the published sources of the RF, official web-sites of the companies, reviews, statistical data and latest research of both Russian and foreign specialists.

\section{Innovative Development Peculiarities of the First-rate Russian Industrial Corporations}

Generalization and structuralization of the disembodied data about production capacities, resource and regulatory basis, amount of financing of enterprises presented on the official websites of Russian Ministry of Industry and Trade, Russian Ministry of Economy and corporative websites (Official sites of corporations, 2015) allowed to reveal the factors of innovative development of the major Russian industrial corporations.

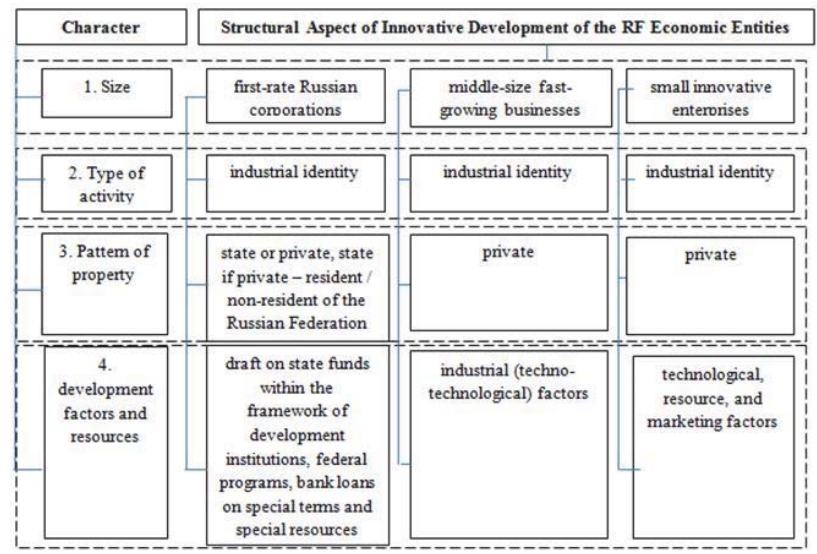

Figure 1. Logical order of research. 
It is proved that alongside with innovative specifics of some kinds of activity (coke and petroleum products manufacturing focusing on ecological innovations, food industries focusing on marketing innovations (Official site of Federal Service of State Statistics, 2015) their innovative development forms have much in common and can be described as institutional referring to their cooperation with the federal innovative development institutions (Bank for Development and Foreign Economic Affairs (Vnesheconombank), RUSNANO Corporation, Innovation center "SKOLKOVO"), participation in federal projects, setting up special departments dealing with innovative development.

For example, machine building plants eagerly participate in planning and realization of technological platforms, cooperate with leading Russian development institutes (defense-industrial sector "Oboronprom"), establish their own industrial-engineering techno-parks (e.g. public corporation "Air Defense Concern Almaz-Antey").

Electric-power industry plants usually set up their own R\&D centers (e.g. "Rosenergoatom" concern, "Inter RAO" group) and innovative development support funds.

Innovative development factors for oil and oil and gas industries include establishing their own research and designing institutes (e.g. Surgutneftegas - research institute "SurgutNIPIneft" and designing institute "Lengiproneftechim").

Nonferrous-metals industry corporations set up technical universities for manpower development and their own scientific base (e.g. UGMK group set up UGMK technical university, URALMECHANOBR set up NIKI), technoengineering centers (e.g. "Rusal") conclude agreements with the state supervisory agencies (e.g. OAO "GMK Norilsk Nickel" with $\mathrm{OOO} \mathrm{"Institute} \mathrm{Gipronickel",} \mathrm{scientific-technical} \mathrm{branch} \mathrm{in} \mathrm{Australia,} \mathrm{agreement} \mathrm{with} \mathrm{Rostechnadzor)}$

Pharmaceutical corporations' innovative development is to a considerable degree determined by participation in large-scale projects within the state sector programs (e.g. OAO "Pharmstandart" takes part in the joint biotechnological project "Generium" within the framework of the import-substitution state program).

Precious-metals industry and food industry set up their own research centers (e.g. AK "Alrosa" and OAO "Polyus Gold"). One of the key factors of building materials industry innovative development is the long-term industry modernization program supported by considerable amount of investment in research and in-house designing and engineering center (Eurocement group).

Large corporations have special resources of both material and non-material character facilitating their innovative development:

Some large corporations have their own raw materials base. E.g. "Baltika" brewery (food industry) owns malt houses, one of them constructed jointly with a French company; "Eurazholding" (iron industry) has its own iron ore and coking coal deposit; "Eurochim" (chemical and petrochemical industries) owns raw materials and hydrocarbon deposits.

E.g. "Rosneft" owns in-house export terminals as well as one of the largest sales retail chain. OOO TK "Eurazholding", "Mechel" group (iron industry) and SUEK (coal-mining industry) have their own trading ports, besides, SUEK and "Eurochim" group (chemical and petrochemical industries) own in-house bulk terminals. "Eurochim" group also has its own sales network, railway transport and depot, port terminals and sea-going vessels, railway transportation centers and railway car repair shops. "llim" group (timber, wood-working and pulp and paper industries) comprises centralized service enterprise "Fintrans" that provides logistics and transportation services to provide an in-house raw materials base.

They have the opportunity to lobby for their interests on federal and regional levels. E.g., participation in business meetings on federal level (OAO "Rosseti" (electro power industry), PAO "Severstal" (iron industry), cooperation with regional authorities and social groups ("Rosneft" (oil and oil and gas industries) is a member of Russian national committee of the world oil congresses, takes part in round-table discussions in the key regions of presence).

Top management structure of the largest Russian corporations evidently proves the above mentioned opportunities:

- working representatives of the bodies of power (Gazprom, Oboronprom, Almaz-Antey, Rosseti, RusGydro, Nizhnekamskneftechim),

- former government employees or governors (LUKOIL, Rosneft, Oboronprom, Inter RAO, Rusal, Alrosa, LSR Group),

- $\quad$ former deputies of the State Duma or former members of the Federation Council, leaders of non-government organizations (Severstal, Eurochim, Norilsk Nickel, Rusal, UGMK, LSR Group, llim Group)

- representatives of the leading Russian innovative development institutes (Oboronprom, Almaz-Antey, Inter RAO, Norilsk Nickel, Polyus Gold),

- members of consultative bodies under the RF government (Severstal, Norilsk Nickel, Rusal, LSR Group, Ilim Group).

Generalization and structuralization of the innovative development factors of Russian industrial corporations 
allowed to classify them roughly into two groups: economic-organizing and others including respectively six and five items (Berkovich and Antipina, 2014; Antipina, 2013). Their branch identity according to 15 types of economic activity is shown in Table 1.

Table 1. Innovative development factors of Russian industrial corporations (sector sample)

\begin{tabular}{|c|c|c|c|c|c|c|c|c|c|c|c|c|c|c|c|c|}
\hline Factor & 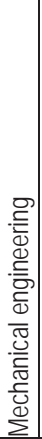 & 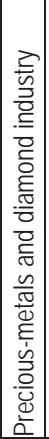 & 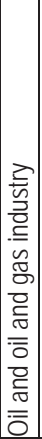 & 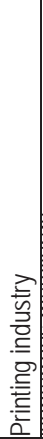 & 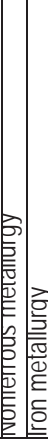 & & & 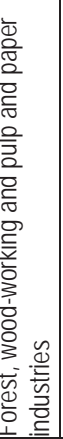 & 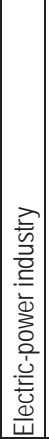 & 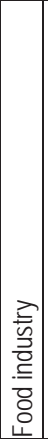 & 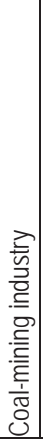 & 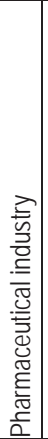 & 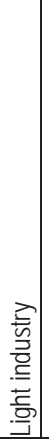 & 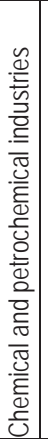 & 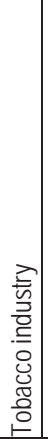 & \\
\hline \multicolumn{17}{|l|}{ Economic-organizational factors: } \\
\hline 1. Considerable amount of R\&D financing & + & + & + & & + & + & & + & + & + & & + & & & & 9 \\
\hline 2. Provision of enterprises with innovative infrastructure objects & + & + & & & ++ & $+t$ & + & & + & + & + & & + & & + & 10 \\
\hline $\begin{array}{l}\text { 3. In-house designing institutes and scientific-production } \\
\text { associations }\end{array}$ & + & + & + & & + & & & & + & + & & & & + & + & 8 \\
\hline $\begin{array}{l}\text { 4. Participation in state innovative sector programs or participation } \\
\text { in their planning }\end{array}$ & + & & + & & + & & & & + & & & + & & & & 5 \\
\hline 5. Own regulatory innovative development base & + & + & + & + & ++ & $+\quad+$ & & + & + & + & + & + & & & & 12 \\
\hline 6. Joint $R \& D$ projects with universities and $R \& D$ institutes & + & + & + & & + & & & & + & & & & & + & & 6 \\
\hline \multicolumn{17}{|l|}{ Other factors: } \\
\hline 7. In-house transportation and logistic infrastructure & & & + & & + & & & & & & + & & & + & & 4 \\
\hline 8. Own raw materials base & & & & & ++ & & & & & + & & & & + & & 4 \\
\hline 9. Advanced sales network & + & + & + & + & ++ & + & + & + & + & + & + & + & + & + & + & 15 \\
\hline 10. Oligarchical management structure & & + & + & & ++ & + & + & + & & & & + & & + & & 8 \\
\hline $\begin{array}{l}\text { 11. Cooperation with federal and regional bodies of state power } \\
\text { and non-government organization }\end{array}$ & + & & + & & ++ & & & & + & + & + & + & & + & & 9 \\
\hline total amount & 8 & 7 & 9 & 2 & 98 & 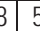 & 5 & 4 & 8 & 7 & 5 & 6 & 2 & 7 & 3 & 90 \\
\hline
\end{tabular}

[Source: compiled by the authors]

As it can be concluded from Table 1, the most significant innovative development factors for the majority of corporations are the following economic-organizing factors: considerable amount of R\&D financing, provision of enterprises with innovative infrastructure objects, in-house designing institutes and scientific-production associations, participation in state innovative sector programs or participation in their planning, own regulatory innovative development base, joint $R \& D$ projects with universities and R\&D institutes. There are other factors including logistics (advanced sales network, inhouse transportation and logistic infrastructure), promotion and lobbying (cooperation with the bodies of state power and non-government organization, oligarchical management structure).

The most important indicator reflecting innovative development of corporations is the form of property - state or private. Analysis of 39 largest industrial corporations ${ }^{1}$ revealed that nearly quarter of them are state-run or partially state

${ }^{1}$ The sampling is based on the data provided by the acknowledged published rating of the largest Russian companies by the leading Russian rating agency "Expert-RA" (Expert 400, 2014) (Gasprom, LUKOIL, Rosneft, OPK "Oboronprom», Volkswagen Group Rus, Concern PVO «Almaz-Antey», Euraz group, Severstal, Novoliprtsk metallurgical plant, OAO»Rosseti», «Inter RAO» Group, "Rusgydro», Sibur, "Eurochim» Group, Nizhnekamskeurochim, GMK «Norilsk Nickel», Rusal, UGMK Group, PepsiCo, Baltika brewery, Nestle Russia, G.T.I. Sales and Marketing, Philip Morris Sales \& Marketing, British American Tobacco - Saint-Petersburg, AK Alrosa, Poljus Gold, Polymetall, SUEK, Sibuglemet Holding, SDS-ugol Holging company, LSR group, Eurocement group, Tarkett Rus, Ilim group, Mondi Sktyvkar LPK, International Paper, Pharmstandart, FGUP «Goznak», Gloria Jeans Corporation) 
owned corporations and companies, including oil and oil and gas corporations (Gasprom, Rosneft), machine building industry (Oboronprom, Almaz-Antey), electro power industry (Rosseti, Inter RAO, RusGydro), precious-metals and diamond industry (Alrosa), printing industry (Goznak).

State-run corporations and partially state owned companies alongside with being the recipients of state support rely on their own innovative development programs including special tools for their financing. E.g. sub-programs of Gazprom and RusGydro innovative environment development include setting up innovative technologies venture funds, holding open innovative projects tenders, creating business incubators and technologies transfer centers (Rating, 2012). Regulations for certain state corporations approved on federal level allow partial government-provided compensation of interest on credit expenditure (FGUP "Goznak"). It should be noted that to some extent such preferences lead to rise of monopolism and lowering of competition.

Innovative development analysis of industrial corporations is closely connected with the analysis of the amount of their development financing, as it is reflected in the study of the loan portfolio structure of total loans among major banks with public ownership such as Sberbank, VTB, Vnesheconombank, Gasprombank, Globexbank taking into account economic activity type and innovative development index (Table 2).

From Table 2 it is clear that banks total loans have their maximum concentration in industries, which have a high index of innovative development: metal industry (7,8\% - VEB, 9,0\% - VTB, 15,9\% - Gazprombank), chemical industry (8,9\% - VEB, 6,0\% - VTB, 15,7\% - Gazprombank), oil and gas industry (9,0\% - VEB, 8,3\% - Globexbank), also machinery manufacturing (6,7\% - VEB, 4,9\% - Sberbank). Customers of such banks are the largest Russian state-run corporations which has been proved by the International Standards of Financial Reporting of Gazprombank (among the clients of Gazprombank there are Gazprom, Rosneft, Lukoil, Evraz, Inter RAO, SUEK, Russian Mail)2, and allows to define partially state-owned banks as financially oligarchical.

Table 2. Branch structure of total loans among major banks with public ownership and index of innovative development of industrial branches in 2014

\begin{tabular}{|l|c|c|c|c|c|c|c|}
\hline Sphere of activity & $V^{\prime} B^{3}, \%$ & $V_{T B}^{4}, \%$ & $\begin{array}{c}\text { Sberbank, } \\
\%\end{array}$ & $\begin{array}{c}\text { Gazprombank } \\
\%\end{array}$ & Globexbank,$\%$ & $\begin{array}{c}\text { Innovative } \\
\text { activity, } \%\end{array}$ & $\begin{array}{c}\text { Innovative goods } \\
\text { range, millions of } \\
\text { roubles }\end{array}$ \\
\hline Shipbuilding & 1,1 & - & - & - & - & - & - \\
\hline Electronic industry & 2,4 & - & - & - & - & 26,9 & 118139,5 \\
\hline Wood processing industry & 4,3 & - & - & - & - & 6,8 & 7562,4 \\
\hline Construction materials industry & 6,5 & - & - & - & - & - & - \\
\hline Food industry & - & - & - & 3,8 & - & 11,0 & 127817,4 \\
\hline Defense industry complex & 3,6 & - & - & - & - & - & - \\
\hline Metal industry & 7,8 & 9,0 & 4,0 & 15,9 & 1,5 & 14,8 & 264827,2 \\
\hline $\begin{array}{l}\text { Aircraft engineering and transportation } \\
\text { service }\end{array}$ & 6,3 & - & & & - & - & - \\
\hline $\begin{array}{l}\text { Machinery manufacturing (except } \\
\text { aircraft engineering) }\end{array}$ & 6,7 & - & 4,9 & - & - & 15,9 & 68797,0 \\
\hline Chemical and petrochemical industry & 8,9 & 6,0 & 2,9 & 15,7 & - & 25,0 & 160977,3 \\
\hline Oil and gas industry & - & 9,0 & 2,5 & 5,0 & 8,3 & 29,0 & - \\
\hline Electrical energy industry & - & 4,0 & 5,2 & 5,9 & 2,4 & 5,3 & 30702,2 \\
\hline
\end{tabular}

Source: compiled by the authors based on the data of official websites of Federal Service of State Statistics, VEB, VTB, Sberbank, Gazprombank, Globexbank]

\footnotetext{
2 Corporative presentation of Gazprombank on ISFR over 9 months of 2015 [Online]. - 2015. - Access mode: http://www.gazprombank. ru/ir/present/GPB_Corporate_Presentation_9M2015_RUS_fin.pdf

3 Vnesheconombank. Annual accounts 2013 [Online]. - 2013. - Access mode: http://static.annual2013.veb.ru/files/ru_Assisting_the_ Development_of_the_National_Economy.pdf

${ }^{4}$ http://www.vtb.ru/ir/presentations/

${ }^{5}$ Sberbank Group results on International Standards of Financial Reporting over 2014 [Online]. - 2014. - Access mode: http://www.sber bank.ru/ru/investor_relations

${ }^{6}$ Corporative presentation of Gazprombank on ISFR over 2014 [Online]. - 2014. - Access mode: http://www.gazprombank.ru/ir/ present/GPB\%20Corporate\%20Presentation\%202014\%20RUS.pdf

${ }^{7}$ On data of consolidated financial reporting over 2014 [Online]. - 2014. - Access mode: http://www.globexbank.ru/. Loans to industries including machinery manufacturing made 10,7\% in 2014
} 
It is important to note that most large private industrial companies are not residents of the Russian Federation (Volkswagen Group Rus, Nissan Manufacturing Rus, Renault Russia, Ford Sollers Holding, PepsiCo Russia, Nestle Russia, LCR Group, Tarkett Rus, Mondi Siktivkar LPK, International Paper, and Phillip Morris International). Involvement of non-residential corporations allows using new technologies of world leading companies which by far has a positive impact on the innovative development of the industrial branch. For example with the participation of world tobacco and food corporations, the following scientific and research centers have been founded: "Phillip Morris International" and unique innovative center "Customer and Client", "Nestle Russia".

\section{Peculiarities of Russian Small- and Middle-Size Business Innovative Development}

Innovative development of small- and middle-size businesses (with the steady annual growth by $20 \%$ and more for at least 5 years) has its peculiarities, one of them being the key role of fast-growing middle-size businesses with their disproportionate contribution into the growth of the country's economy ${ }^{8}$. Fast-growing middle-size businesses generate the amount of proceeds nearly equal to large companies. Russian middle-size business provides for $44,4 \%$ of proceeds and big business provides for $55,6 \%$, whereas in Italy $21 \%$ of proceeds is provided by middle-size business and $45 \%$ by big business, in Sweden 39\% and 44\% respectively, in Japan 32\% and 25\% (Gurova T. et al, 2008).

The stated structural approach identifies the innovative development structural peculiarities of middle-size fastgrowing businesses from the industrial aspect.

Industrial structure analysis of middle-size businesses, based on the study of their activities presented in the special project "Russian fast-growing middle-size companies" (Polunin and Yudanov, 2013), allows to identify 39 industrial middle-size companies (out of 208) ${ }^{9}$ in 9 industrial branches (Polunin and Yudanov, 2013; Totina, 2012). Summarizing disembodied data and economic performance of these companies it is possible to reveal two groups of ultra-fast innovative development factors:

- industrial (techno-technological) factors: in-house laboratory or R\&D center; state-of-the-art equipment including by the well-known western companies; modern quality control and management systems based on international experience; considerable investment in production; cardinal industry modernization; adoption of innovations; cooperation with the leading research institutes and IT-companies;

- other factors: technological compliance with the customer technical requirements; partnership with the largest corporations including foreign ones; own sales network; own raw materials base; location close to knowledge city; ramified sourcing; in-house merchandizing centers. The mentioned above factors are structured and presented in Table 3.

As it is can be concluded from Table 3, The most significant innovative development factors are in-house laboratories or R\&D centers; state-of-the-art equipment and modern quality control and management systems, reflecting specific character of economic activity. On the other hand in certain industries a great deal of importance is attached to such comparative advantages as ramified sourcing and in-house merchandizing centers (light industry), own raw materials base (building materials manufacturing, coal-mining industry), location close to knowledge city (fragrance and cosmetic industry).

Practice has shown that in Russia fast-growing medium-sized enterprises are the creators of "blue oceans" unknown and competition-free spaces, i.e. they are non-existent economic sectors (Kim and Mobourn, 2015). Nevertheless nowadays there are cases when industrial fast-growing medium-sized enterprises work in certain branches (the so called "crimson oceans") and they outdistance competitors on the basis of creation of adopted practices ("Spassky mechanical plant" (mechanical engineering), "SMART company" (food industry), "Samara plant of laminated plastics" (building materials industry), "Splat company" (perfume and cosmetic production), "REEF-Micromramor" (mining industry). In other words contemporary Russian industrial fast-growing medium-sized enterprises, being representatives of "crimson oceans" from the industrial point of view, partially use the "blue ocean" strategy (mastering free markets without creating new ones) within the framework of innovative super-fast development.

\footnotetext{
${ }^{8}$ The term middle-size company was proposed by Birch D. L. He defined that $4 \%$ of total number of companies create up to $70 \%$ of new jobs which was proved later in research by Storey D.J., Daunfeldt S.-O.

${ }^{9}$ See more (Berkovich and Antipina, 2014)
} 
Table 3. Factors of innovative super-fast development of Russian industrial mid-sized companies.

\begin{tabular}{|c|c|c|c|c|c|c|c|c|c|c|c|c|c|}
\hline \multirow[b]{2}{*}{ Representatives, subject of the RF } & \multicolumn{6}{|c|}{$\begin{array}{l}\text { Economic organizational (techno- } \\
\text { technological) }\end{array}$} & \multicolumn{6}{|c|}{ Other factors } & \multirow[b]{2}{*}{ 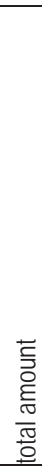 } \\
\hline & 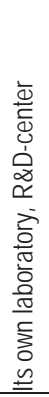 & 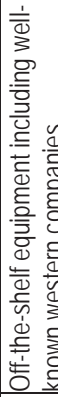 & 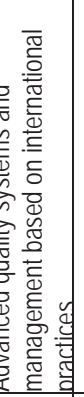 & 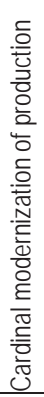 & 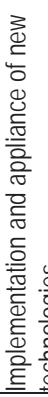 & 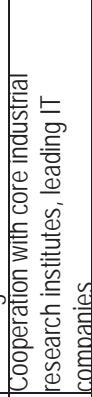 & 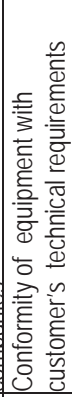 & 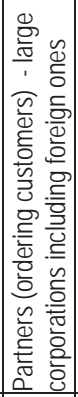 & 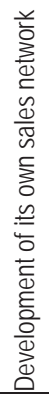 & 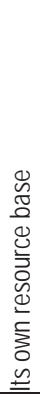 & 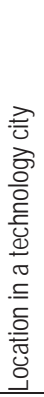 & 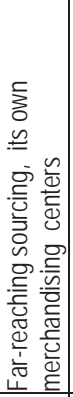 & \\
\hline Machinery manufacturing 10 & + & + & + & & & & + & + & & & & & 5 \\
\hline Food industry11 & + & + & + & + & + & + & & + & + & & & & 8 \\
\hline $\begin{array}{l}\text { Manufacturing of construction } \\
\text { materials }{ }^{12}\end{array}$ & + & + & & & + & & & & + & + & & & 5 \\
\hline $\begin{array}{l}\text { Perfume and cosmetic } \\
\text { production }^{13}\end{array}$ & + & & + & & + & + & & & & & + & & 5 \\
\hline Mining industry ${ }^{14}$ & & & & & + & & & + & & + & & & 3 \\
\hline Metal industry ${ }^{15}$ & & + & & & + & & & & & & & & 2 \\
\hline Textile industry ${ }^{16}$ & + & & & & & + & & & & & & + & 3 \\
\hline Chemical industry ${ }^{17}$ & + & + & & & & & & & & & & & 2 \\
\hline Oil and gas industry ${ }^{18}$ & & + & & & & & & & & & & & 1 \\
\hline total amount & 6 & 6 & 3 & 1 & 5 & 3 & 1 & 3 & 2 & 2 & 1 & 1 & 34 \\
\hline
\end{tabular}

[Source: based on rating of fast growing medium-sized enterprises, 2007-2011, official sites of the following mid-sized companies]Along with fast-growing medium-sized enterprises fast-growing medium-sized enterprises fast-growing medium-sized enterprises there are other modifications of small enterprises including "new business" (New business, 2015) - new promising representatives of medium-sized enterprises among them microenterprises with 2 to 150 employees which may be called "blue ocean" creators.

All representatives of "new business" in Russia are innovative in the broad sense of the word. They create new markets, new goods, services, innovative organizations, technologies. The authors analyzed scope of activity of 142 representatives of "the new business"19, their innovative development peculiarity being fashion and style consulting, hostel services, co-working, talent agency. These are free markets capturing of which became possible due to new organizational and marketing practices. By all means, such enterprises are not innovative from the technological point of view but they offer organizational and economic solutions which can change habitual procedures or objects, they implement marketing innovations.

10000 "Spassky mehanichesky zavod» (Primorski Krai), 000 "Vagonno-kolesnaya masterskaya» (Belgorod oblast), 000 «Ruskomtrans» (Nizhni Novgorod oblast), 000 "Vostochnaya polimernaya kompaniya» (St. Petersburg)

11000 «Tehnolat» (Kaliningrad oblast), 000 "Obuchovsky myasokombinat» (Belgorod oblast), ZAO «Smart» (Chelyabinsk oblast), 000 "Ugovskoy Kombinat Molochnyh Productov» (Perm Krai), OAO zavod "Semikarakorsky» (Rostov oblast), 000 «Myasokombinat Vladi"» (Samara oblast)

12000 "Metalloprofil» (Voronezh oblast), 000 "Prionezhskaya gornaya kompaniya" (Republic of Karelia), 000 «FinansByuro» (Republic of Karelia), 000 «Samarsky zavod sloistyh plasticov» (Samara oblast)

${ }^{13} 000$ «Splat-Kosmetika» (Moscow), «Aerostar Contract» (Smolensk oblast), 000 «Bioflavon» (Kaluga oblast)

${ }^{14} \mathrm{OAO}$ "Tehnologicheskoye Bureniye» (Moscow), OOO "RIF-Micromramor" (Chelyabinsk oblast)

15000 «Oktan» (Stavropol Krai)

${ }^{16} \mathrm{OAO}$ «Gloria Jeans» (Rostov oblast)

17000 «Bashplast» (Republic of Bashkortostan), 000 «SK-Plast» (Sverdlovsk oblast)

${ }^{18} 000$ «Tomskneftepererabotka» (Tomsk oblast)

${ }^{19} \mathrm{http}: / /$ expert.ru/dossier/story/novyij-biznes/ 
Along with it "new business" representatives are the most interesting because they use and produce absolutely new technological goods. Study of such activity of 24 economic players (17\% of the total number) in 23 spheres allowed to distinguish the main factors (technological, resource, and marketing) of their innovative development:

Technological factors create unique new technologies, unique innovative product, an innovative approach to the problem or breakthrough idea, non-stop research, making created goods and technologies along with foreign innovative technologies more perfect ("Genotek", device "Master of posture", "Neurobotics", "Observer", "NanoServ", "Magador", "Mixville").

Resource factors mobilize state finances or research institutes, state order, cooperation with objects of innovative infrastructure, its laboratories and unique features of raw materials, involvement of "SKOLKOVO" innovative center graduates as initiators of the project ("BiofoodLab" (nut bars production), "Conelum" (biotechnologies), team of professionals;

Marketing factors mean creating new markets, providing an individual approach and accompanied services.

Given factors are structured on spheres of activities and presented in table 4.

From table 4 it is clear that Russian "new business" focuses on work in a professional team, unique new technology, have an innovative approach to the problem or breakthrough idea, creating new markets and unique innovative product.

\section{Main Conclusions}

The issue of innovative development peculiarities is updated taking into account the size of different economic entities, pattern of ownership, their industrial identity and development factors and resources.

As it can be concluded the innovative development of the large industrial corporations has its peculiarities connected with a special role played by the state as the owner, that along with the formation of their own resource base (raw materials and infrastructure) facilitates the participation of the business in federal special-purpose programs, getting loans on special terms in major banks, participation of corporation top-management representatives in the bodies of state power.

Table 4. Factors of innovative development of "new business" in Russia

\begin{tabular}{|c|c|c|c|c|c|c|c|c|c|c|c|c|c|c|c|c|}
\hline \multirow[b]{2}{*}{ Sphere of activity } & \multicolumn{6}{|c|}{ Technological } & \multicolumn{7}{|c|}{ Resource } & \multicolumn{2}{|c|}{ Marketing } & \multirow[b]{2}{*}{ 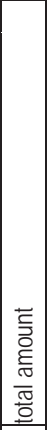 } \\
\hline & 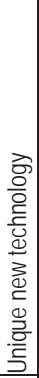 & 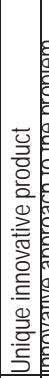 & 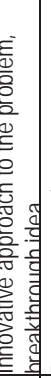 & 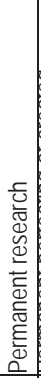 & 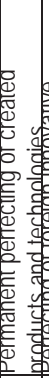 & 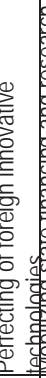 & 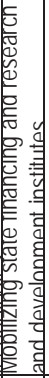 & 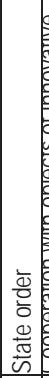 & 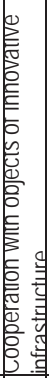 & 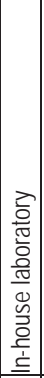 & 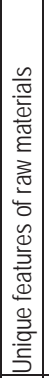 & 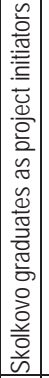 & 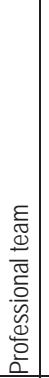 & 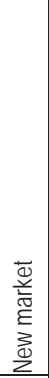 & 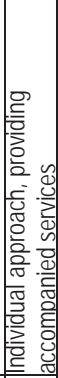 & \\
\hline 1. Production of innovative microelectronics & & + & + & & & & + & & 7. & & & & + & + & & 5 \\
\hline 2. Genetic research & & & + & & & & & & + & & & & + & + & & 4 \\
\hline 3. Production of advanced technological machinery for fuel economy & + & + & + & & & & & & & & & & + & & & 4 \\
\hline $\begin{array}{l}\text { 4. Production of musle and construction materials on the basis of rice } \\
\text { hulls }\end{array}$ & + & + & + & & & + & & & & + & & & + & + & & 7 \\
\hline 5. Diagnostics, technology and equipment & + & + & + & & & & & & & & & & + & + & & 5 \\
\hline 6. Innovative heating systems & + & + & + & + & & & & & & & & & + & + & & 6 \\
\hline 7. Production of battery vehicles & + & + & & & & & & & & & & & + & + & & 4 \\
\hline 8. Processing soft roofing materials & + & & + & & & & & & & & & & + & & & 3 \\
\hline 9. Medical equipment & + & + & + & & & & & & & & & & + & + & + & 6 \\
\hline 10. Nanoscale technologies & + & + & + & + & & & + & + & + & + & + & & + & & & 10 \\
\hline 11. Cancer diagnostics & + & & + & & & & + & & + & & & & + & & & 5 \\
\hline 12. Production of wakefulness controlling machinery & + & + & + & & & + & & & & & & & + & + & & 6 \\
\hline 13. Technologies for hot metal coating of steel constructions & + & & + & & & & + & & & & & & + & & & 4 \\
\hline 14. Climate controlling technologies & + & & + & & + & & & & & & & & + & + & + & 6 \\
\hline
\end{tabular}




\begin{tabular}{|l|c|c|c|c|c|c|c|c|c|c|c|c|c|c|c|c|}
\hline 15. Production of radio electronics & + & + & + & & + & & & & & & & & + & + & + & 7 \\
\hline 16. Production of individual kits & + & + & + & & & + & & & & & & & + & & + & 6 \\
\hline 17. Medicine & & & + & & & & + & & & & & & + & & & 3 \\
\hline 18. 3D-printing & & & + & & & & & & & & & & + & + & + & 5 \\
\hline 19. Nut bars production & + & & + & & & & & & + & & & + & + & + & & 5 \\
\hline 20. Chocolate production & + & & + & & & & & & & & & & + & + & + & 5 \\
\hline 21. Biotechnologies & + & & + & & & & & & & & & + & + & & & 4 \\
\hline 22. Robotechnics & + & + & + & & & & & + & & & & & + & + & & 6 \\
\hline 23. Production of lime scale cleansing bacteria and service provision & + & + & + & & & & & & & & & & + & + & + & 6 \\
\hline total amount & 19 & 13 & 22 & 2 & 2 & 3 & 5 & 2 & 4 & 2 & 1 & 2 & 23 & 15 & 7 & 122 \\
\hline
\end{tabular}

[Source: based on «New Business» project data]

It is revealed that superfast innovative development of industrial fast growing medium-sized enterprises is determined both by typical factors and branch peculiarities, carried out on the basis of new equipment and participation of international brands, continuous rationalization of technologies, its own raw materials base or using raw materials of European suppliers, its own sales network, scientific and research labs and design centers and inclusion in vertically integrated holdings.

Creating new markets ("blue oceans"), development and supply of a high quality innovative unique products, service or technology and creating unique competence are main factors of innovative development of "new business" in Russia. Innovative development of such enterprises is typically of non-production character (technologically innovative companies account for only $17 \%$ of "new business" in Russia), but they introduce mainly marketing innovations.

\section{References}

Antipina, N.I. (2013). Factors of Innovative Development of Leading Industrial Companies: Branch Aspect. Kazan Nauka, 11, 70-73.

Berkovich, M.I., Antipina, N.I. (2014). Institutional Provision of Innovative Activity on Mesoeconomic Level: Constructive and Evaluative Aspect. Kostroma: Published by Kostroma State Technological University, pp. 166-167.

Birch, D., Medoff, J. (1994): Gazelles. In: "Labor Markets, Employment Policy, and Job Creation" L. Solomon, A. Levenson (Eds.). Westview: Boulder, Co. p. 159-168.

Expert 400 - rating of leading Russian companies (2014). [Online] Access mode: http://expert.ru/dossier/rating/expert-400/.

Gurova, T., Vinjkov, A., Polunin, Y., Yudanov, A. (2008). How to create a middle-size company. Expert, 10 (599). [Online] Access mode: $h$ htp://expert.ru/expert/2008/10/delat_sredniy_biznes/

Kim, Ch., Mobourn, R., Blue Ocean Strategy (date of access 10.08.2015). How to Create a Free Market and Stop Being Afraid of Competitors. [Online] Access mode: http://www.digest.kyivstar.ua/static/uploads/pdf/Blue_ocean_strategy.pdf.

New Business (2015) [Online] Access mode: http://expert.ru/dossier/story/novyij-biznes/

Official site of Almaz - antey (2015). [Online] Access mode: http://www.almaz-antey.ru/353/.

Official site of Alrosa (2015). [Online] Access mode: http://www.alrosa.ru/.

Official site of EVRAZ (2015). [Online] Access mode: http://www.evraz.com/ru/about/.

Official site of Eurocement (2015). [Online] Access mode: http://www.eurocement.ru/cntnt/rus/company/investicionnaya-programma. html.

Official site of Federal Service of State Statistics (2015). [Online] Access mode: http://www.gks.ru/.

Official site of Gazprom (2015). [Online] Access mode: http://www.gazprom.ru/about/strategy/innovation/.

Official site of Goznak (2015). [Online] Access mode: http://www.goznak.ru/innovations/.

Official site of Ilim Group (2015). [Online]Access mode: http://www.limgroup.ru/about-company/.

Official site of Inter RAO (2015). [Online] Access mode: http://www.interrao.ru/company/strategy/.

Official site of Nestle (2015). [Online] Access mode: http://www.nestle.ru/.

Official site of NLMK (2015). [Online] Access mode: http://nlmk.com/.

Official site of Norilsk Nickel (2015). [Online] Access mode: http://www.nornik.ru/kompaniyal.

Official site of Pharmstandard (2015). [Online] Access mode: http://pharmstd.ru/page_159.html.

Official site of Polymetall (2015). [Online] Access mode: http://www.polymetal.ru/about-us/strategy-and-business-model.aspx?sc_lang= ru-RU.

Official site of Polyus Gold (2015). [Online] Access mode: http://www.polyusgold.com/ru/.

Official site of Rosneft (2015). [Online] Access mode: http://www.rosneft.ru/.

Official site of Rosseti (2015). [Online] Access mode: http://www.rosseti.ru/about/mission/.

Official site of Rusal (2015). [Online] Access mode: http://www.rusal.ru/development/innovations/.

Official site of Severstal (2015). [Online] Access mode: http://www.severstal.com/rus/about/.

Official site of SUEK (2015). [Online] Access mode: http://www.suek.ru/page.php?id=601.

Official site of UGMK (2015). [Online] Access mode: http://www.ugmk.com/ru/company/projects/. 
Official site of United Industrial Corporation «Oboronprom» (2015). [Online] Access mode: http://www.oboronprom.ru/about.

Polunin, Y., Yudanov, A. (2013) Fragile Force of Mid-Sized Companies. Expert, 20. [Online] Access mode: http://expert.ru/expert/2013/ 20/hrupkaya-sila-srednego-biznesal

Rating of Projects of Innovative Development of State Corporations and Companies with State Participation (2012). Rating Agency «Expert RA». [Online] Access mode: http://raexpert.ru/editions/bulletin/27_06_12/inno_raz_27_06_12.pdf

Totina M. (2012). Is It Easy to Be a Mid-Sized Company? Business Bridge of Southern Urals «Line». [Online] Access mode: http://www.kursdela.biz/journal/9534/. 